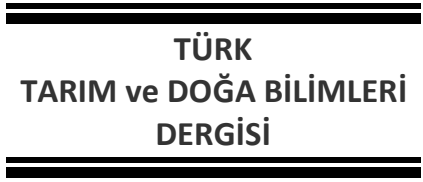

TÜRK

DERGISI

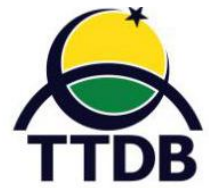

www.dergipark.gov.tr/turkjans

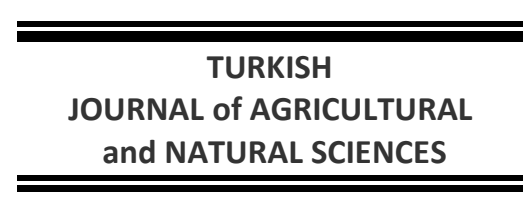
and NATURAL SCIENCES

Araştırma Makalesi

\title{
Konya Kapalı Havzası İçin Gelecekteki Olası Hidrolojik Kurak Dönemler
}

\author{
İsmail TAŞ ${ }^{*}$, Yusuf Ersoy YILDIRIM², ìsmail ARAS ${ }^{3}$ \\ ${ }^{1}$ Çanakkale Onsekiz Mart Üniversitesi. Ziraat Fakültesi Tarımsal Yapılar ve Sulama Bölümü, Çanakkale \\ ${ }^{2}$ Ankara Üniversitesi Ziraat Fakültesi Tarımsal Yapılar ve Sulama Bölümü, Ankara \\ ${ }^{3}$ Tarımsal Araştırmalar ve Politikalar Genel Müdürlüğü, Ankara \\ *Sorumlu yazar: tas_ismail@yahoo.com
}

Geliş Tarihi: 28.03.2020 Düzeltme Geliş Tarihi: 02.06.2020 Kabul Tarihi: 09.06.2020

\section{$\overline{\mathrm{O} z}$}

İklim değişikliği ile ilgili çok sayıda farklı görüş ve senaryo vardır. Her bir görüşün ortaya koyduğu sonuçlara bağlı olarak karşılaşılacak muhtemel sorunlar belirlenmelidir. Bu sorunların çözümüne yönelik gerekli çalışmaların yapılması sürdürülebilir üretim için büyük önem arz etmektedir. Bu bağlamda, gelecekteki olası hidrolojik kurak dönemlerin tahmin edilmesi, suyun doğru yönetilmesinde en önemli öğelerin başında gelmektedir. Gelecekteki kurak dönemlerin tahmin edilmesi, başta karar vericiler olmak üzere tüm su kullanıcı sektörleri doğrudan ilgilendirmektedir. Bilindiği gibi Standardize Yağış İndisi (SPI) hem kullanım kolaylığı hem de sonuçlarının yorumlanması bakımından dünyada en yaygın kullanılan kuraklık indislerinden biridir. SPI, meteorolojik, tarımsal ve hidrolojik kurak dönmelerin saptanmasında bilim dünyasında kabul gören indislerdendir. Yapılan bu çalışmada, HadGEM2 küresel iklim modeline göre 2100 yılına kadar Konya Kapalı Havzası için tahmin edilen yağış serileri kullanılmıştır. Söz konusu seriler, hem kötümser (RCP 8.5) ve hem de iyimser (RCP 4.5) senaryo sonuçlarını içermektedir. Temin edilen aylık yağış serileri, SPI analizine tabi tutulmuş ve 2100 yılına kadar olası kurak dönemler belirlenmiştir. Yapılan analizler ve hesaplamalar sonucunda RCP 4.5 senaryosunda göre Konya Kapalı Havzasında 2100 yılına kadar altı kurak devre/dönem (2026-2027, 2044-2048, 2062-2063, 2087-2088; 2090-2091 ve 2097-2098) belirlenmiştir. RCP 8.5'e göre ise dört kurak dönem (2026-2027, 2060-2063, 2074-2075 ve 2092- 2097) belirlenmiştir. Belirlenen hidrolojik kurak dönemlerin şiddetlerinin havza içerisindeki değişimi şiddet dağılım haritaları ile gösterilmiştir. Elde edilen sonuçlara dayanarak, Konya Kapalı Havzasında yaşanması muhtemel olan hidrolojik kurak dönemlerde oluşacak su krizine karşı gerekli önlemelerin alınması ve su yönetimi planlarının hazırlanması gerekmektedir. Söz konusu yaşanacak kuraklıkların etkilerinin azaltılması, hem ülke ekonomisi hem de bölge üreticisi açısından büyük önem arz etmektedir.

Anahtar Kelimeler: Hidrolojik kuraklık, SPI, HADGEM2, kuraklık şiddet haritaları

\section{Possible Hydrologic Drought Periods in Future for Konya Closed Basin}

\section{Abstract}

There are several different opinions and scenarios on climate change. Potential problems to be encountered should be identified based on the each opinion. It is of utmost importance for sustainable production to carry out the necessary researches to solve these problems. In this context, the prediction of possible future hydrological drought periods is one of the most important elements for sustainable management of water. Estimation of future drought periods is directly related to all water-using sectors, especially for decision-makers. As it is known, Standardized Precipitation Index (SPI) is one of the most widely used drought indices in the world in terms of both ease of use and interpretation of its results. SPI is one of the indices accepted in the scientific world in the determination of meteorological, agricultural and hydrological drought cycles. In this study, estimated monthly rainfall series until 2100, which is obtained HadGEM2 global climate model, were used for Konya Closed Basin. The time series includes both pessimistic (RCP 8.5) and optimistic (RECP 4.5) scenario results. The obtained rainfall series were subjected to SPI analysis and possible drought periods until 2100 were determined. As a result of the analyses and calculations, six drought terms/periods (2026-2027, 2044-2048, 2062-2063, 
2087-2088; 2090-2091 and 2097-2098) were determined in Konya Closed Basin until 2100 according to the RCP 4.5 scenario. At the same time, four drought periods (2026-2027, 2060-2063, 2074-2075 and 2092-2097) were determined for RCP 8.5 scenario. The changes of severity of the determined hydrological drought periods within the basin are shown by maps of severity distribution. Based on the results obtained, it is necessary to take relevant actions against the water crisis that will occur in the hydrological drought periods in Konya Closed Basin and prepare water management plans. Reducing the impacts of these droughts is of great importance for both regional growers and the national economy.

Keyword: Hydrological drought, SPI, HadGEM2, drought severity maps

\section{Giriş}

İklimdeki herhangi bir dalgalanma, başta hidrolojik çevrimi etkiler. Dolayısıyla su kaynakları bundan yerel, bölgesel ve küresel ölçekte etkilenir. Bu nedenle su kaynaklarının yönetimi ve bunların dağıtımı üzerine ciddi araştırmalar yapılarak, karşılaşılacak problemler için çözüm önerileri geliştirilerek gerekli önlemlerin alınması gerekmektedir. Hali hazırda dünyanın farklı bölgelerinde su kaynakları konusunda ciddi sorunlar bulunmakta ve bu gelecekte de artarak devam edecektir. Su kaynakları 21. yüzyılın en değerli emtiası haline gelmiştir. Tarihe bakıldığında dünyanın farklı bölgelerinde su kaynaklarının alan ve zaman bakımından farklı davranışlar sergilediği görülmektedir. Bundan sonra var olan her su kaynağı için yeniden geliştirme çalışmaları, iklimsel değişkenliklerle birlikte ele alınarak değerlendirilmelidir. Dünyanın farklı bölgelerindeki nehir akışlarında görünür şekilde artma ve azalma eğilimleri bulunmaktadır. Bu durumu sadece bölgelerdeki sıcaklık ve yağıştaki değişimlere bağlamak doğru değildir. İklimdeki dalgalanmalar, nehir akışları ile birlikte yeraltı suyunun beslenmesinde de önemli etkiler yapmaktadır. Dünyadaki iklimle ilgili geliştirilen senaryoların bazıları kimi bölgelerde tutarlılık gösterirken, büyük bölümünde beklenen tutarlık zayıf kalmaktadır. Sıcaklıktaki artış, su kalitesinde düşmeye neden olabilir ancak bazı bölgelerdeki akışların artışına bağ Iı olarak bu durum kısmen de olsa telafi edilebilmektedir. iklimde meydana gelen olumsuzluklar su kaynakları üzerinde büyük etkilere sahiptir. Söz konusu etkileri sadece nehir akış hacmindeki azalma, zamanlamadaki problemler (kar erimesi), ve yeraltı suyunun beslenmesindeki sorunlarla sınırlandırmak doğru bir yaklaşım olmaz. Aynı zamanda sistem özelliklerine, sistemin üzerinde meydana gelen değişken baskılara, sistem yönetim evrelerine ve nihayet iklim değişikliğine yönelik tedbirlerin uygulanmış olmasına bağlı olarak değişkenlik gösterebilmektedir (Şen, 2005). Bazı su depolama yapıları, uzun dönemli su ihtiyaçlarını karşılayacak özelliklerde iken bazıları ise tek yıllık su ihtiyacını karşılama özelliğine sahiptir. Diğer bir ifadeyle bir yılda depolanan su, aynı yılın ihtiyaçlarını karşılamada kullanılmaktadır. Temelde yıllık intiyaçları karşılayacak özelliklerdeki yapıların hemen hemen tamamı belli bölgedeki sulama suyu ihtiyaçlarını karşılamaya yönelik depolama yapılardır. Bu yapılar, hem meteorolojik kuraklıktan hem de tarımsal kuraklıktan doğrudan etkilenirler. Genellikle büyük su depolama yapıları, çok daha uzun dönemlerdeki su gereksinimlerini karşılayabilecek özelliklere sahip olup sadece meteorolojik ve tarımsal kuraklıklardan etkilenmemekle birlikte, depolama kapasitesine bağlı olarak bazı hidrolojik kurak dönemleri de rahatlıkla tolere edebilmektedir. Havzanın tamamında içme-kullanma suyu, çevresel su ihtiyacı, sanayi, enerji, maden, hayvancılık, su ürünleri, turizm ve ticari su sektörlerinin su talepleri tüm kuraklık koşullarında \%100 oranında karşılanacaktır. Ancak tarım sektörü su talebi hali hazırda karşılanamazken kurak şartlarda karşılanma oranı çok daha fazla düşecektir. Beyşehir, Konya Çumra ve Karaman Ayrancı alt havzalarında tarım sektörü su ihtiyacı normal durumda \%90 seviyelerinde karşılanabilirken, çok şiddetli kurak koşullarda karşılanabilirlik oranı \%75'lere düşmektedir. Altınekin alt havzasında ise şiddetli kurak koşullarda karşılanabilirlik oranları \%35 seviyesine kadar düşmektedir. Sulama verimliliğindeki artışa rağmen 2040 yılında çok şiddetli kuraklık şartlarında karşılanabilirlik oranı \%48 seviyesine ancak yükselebilmektedir. Benzer bir durum YÜS potansiyeli oldukça düşük olan Cihanbeyli-Yeniceoba, Aksaray ve Misli alt havzaları için de geçerlidir. Tarım sektörü su ihtiyacının karşılanabilmesi için havzanın kuzeyindeki alt havzalarda kullanılmak üzere havza dışından su transferi yapılması ve havzada oluşan arıtılmış atık suların yeniden kullanımı alternatiflerinin değerlendirilmesi gerekmektedir (Anonim, 2019).

Meteorolojik kuraklık analizi denince akla ilk gelen SPI analizidir. Hesaplama sistemi kolay olup kuraklık analiz çalışmalarında en yaygın kullanılan kuraklık indisidir. SPI girdi 
parametresi olarak aylık yağış verilerini kullandığından dönemsel meteorolojik kuraklıkların tespitinde önemli bir araçtır (McKee ve ark., 1993). SPI analizlerinde meteorolojik kuraklığı daha çok temsil etmesi sebebiyle 1 aylık veya 3 aylık SPI analiz sonuçları değerlendirilmektedir (Gürler, 2017). Hidroloji kuraklık için $6-24$ ay veya daha fazla için SPI analizi iyi sonuçlar verebilir (WMO, 2012). Karmaşık bir yapısı olan kuraklık sürecini izlemek amacıyla geliştirilmiş indislerden, Palmer Kuraklık şiddeti indisi ile Standartlaştırılmış Yağış Indisini karşılaştırılmıştır. PDSI, ilgili bölgenin güncel (on günlük, 20 günlük, aylık, mevsimlik, yıllık, vb.) hava sıcaklığına, uzun dönemli hava sıcaklığına ve dolayısıyla buharlaşma terleme sürecine çok sıkı bağlı olmasının yanı sıra, toprak su içeriğine de bağlıdır. Sonuç olarak, yalnız yağış ve uzundönem yağışlarının eklemeli olasılık dağılımının Gauss (Normal) dağılımıma dönüştürülerek elde edilen SPI değerlerinin farklı desenler göstermesi çok açıktır. Başka bir deyişle, bir bölge üzerinde hem yağış hem de toprak türü ve oradan olan buharlaşma terlemeye bağlı olan PDSI ile 12 aylık SPI değerlerinin değişimleri arasında çok kuvvetli ilişkiler belirlenmiştir. Bu ilişkilerin çok kuvvetli olmasının en temel nedeni, PDSI'nin ardışık olarak yıl (12 ay) zaman ölçeğinde hesaplanmasından ileri geldiği varsayılmıştır. Ayrıca, elde edilen sonuçlara bağlı olarak önerilecek bir başka önemli sonuç ise, 12-aylık SPI değerlerinin büyük bir güven düzeyinde PDSI yerine kullanılabilecek olmasıdır. Başka bir deyişle, toprak su içeriği kapasitelerinin elde edilmesinin olanaksız ya da pahalı olduğu durumlarda, 12 aylık SPI indisinin kullanılması önerilebilir (Tatlı ve Türkeş, 2011).

Yapılan bu çalışmada, Meteoroloji Genel Müdürlüğü tarafından geliştirilen HadGEM2 küresel iklim modeli kullanılarak RCP 4.5 ve RCP 8.5 iklim senaryolarının çalıştırılmasıyla 2100 yılına kadar Konya Kapalı Havzasının aylık ortalama yağış verileri kullanılarak 12 aylık SPI analizi yapılmıştır. Böylelikle Konya Kapalı Havzası için 2100 yılına değin olasılık dahilindeki şiddetli ve aşırı kurak sınıftaki hidrolojik kurak dönemler belirlenmiştir. Ayrıca belirlenen bu dönemlerin büyüklüklerinden yararlanılarak jeoistatistiksel yöntemle alan şiddet dağılım haritaları üretilerek yorumlanmıştır.

\section{Materyal ve Metot Çalışma Alanı ve Toprak Özellikleri}

Orta Anadolu Platosunda yer alan Konya Kapalı Havzası, güneydoğusu ve güneybatısı yüksek dağlarla çevrilidir (Şekil 1a). Eğim açsından orta kısım düz ve düze yakın bir plato özelliği sergiler. Ortalama denizden yüksekliği 1000 m'dir. Güney sınırında bu değer 3000 m’lere kadar yükselerek Orta Toros Dağlarının kuzeyini içerisine alır. Havzada genel olarak güneyden kuzeye ve batıdan doğuya doğru gittikçe yükseklik azalma gösterir. Havza sınırlarında ovalar, platolardan sonra en fazla alanı kaplamaktadır. Havzanın merkezde Konya ve Çumra ovaları bulunurken, doğusunda Aksaray, Ereğli, Karapınar, Niğde ve Bor; kuzeyinde Cihanbeyli ve Şereflikoçhisar; batıda Beyşehir ve Seydişehir; güneyde Karaman ve Suğla ovaları yer almaktadır. Konya Kapalı Havzası hidrolojik açıdan toplam 9 adet alt havzaya ayrılır (Şekil 1b). Söz konusu alt havzalar ve bunların kapladığı alan Çizelge 1'de sunulmuştur. Yüzölçümü bakımından en fazla yüzey alanı 5 numara ile numaralandırılan Aksaray alt havzası olup 10569 km²'dir. En küçük ise Şereflikoçhisar alt havzası olup 1463 $\mathrm{km}^{2 \prime}$ lik yüzey alanına sahiptir.

DSi verilerine göre bölgede yaklaşık 3 milyon ha tarıma elverişli arazi bulunmaktadır. Mevcut su kaynaklarına ilişkin projelerin tamamen geliştirilmesi ve suyun tasarruflu kullanılması koşulunda ancak bu arazinin 1/3'ünden (1.1 milyon ha) biraz fazlasının sulanabilmesi hedeflenmektedir. Tarıma elverişli arazinin tamamen sulanabilmesi için ise en az 7 milyar $\mathrm{m}^{3}$ daha suya ihtiyaç duyulmaktadır. $\mathrm{Bu}$ nedenle havza için hazırlanan raporların büyük bölümünde bölgede yapılacak sulu tarım faaliyetlerinin mutlaka suya göre yapılması önemi üzerinde durulmaktadır. Konya ovası jeolojik formasyonlara bağlı olarak farklı toprak tiplerine sahiptir. Ovanın güneydoğu ve doğusundaki volkanik kökenli arazi üzerinde kalkersiz kahverengi topraklara; ovanın kuzey ve güneyindeki kalkerli sahalarda kırmızıkahverengi topraklara rastlanır. Ova tabanında ise akarsuların getirmiş olduğu periyodik karakterli alüvyon üzerine alüvyal topraklar; killi ana materyal üzerinde ise yaygın vertisoller; bataklık sahalarda ise yaygın şekilde hidromorfik alüvyal topraklar sıklıkla yer almaktadır (Anonim, 2012). 


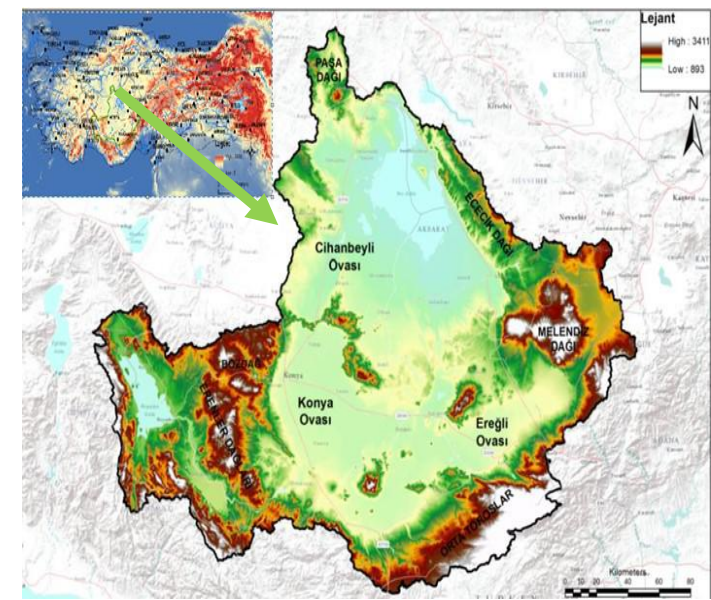

(a)

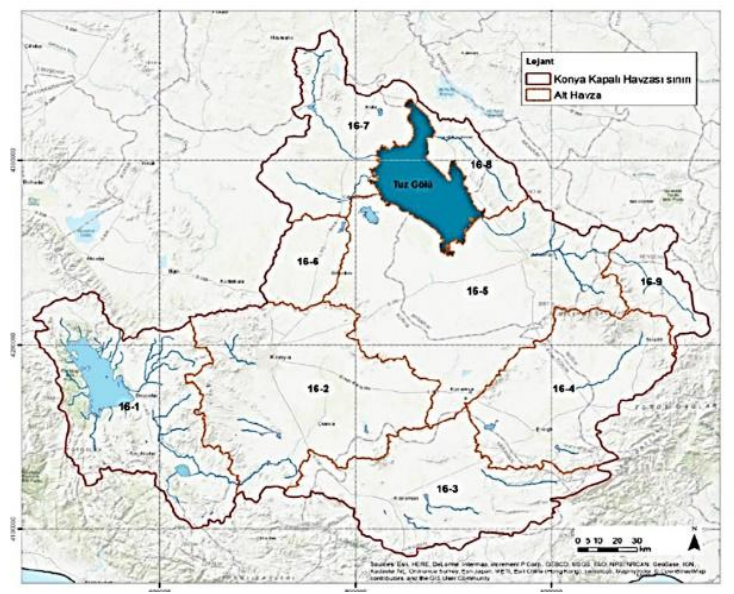

(b)

Şekil 1. Konya kapalı havzasının konumu (a) ve Alt Havzaları (Anonim, 2018) (b)

Çizelge 1. Alt Havzaları ve yüzölçümleri

\begin{tabular}{llc}
\hline Alt Havza Kodu & Alt havzanın adı & Yüzölçümü $\left(\mathrm{km}^{2}\right)$ \\
\hline 43846 & Beyşehir-Kaşaklı & 7308 \\
43877 & Konya-Çumra-Karapınar & 8737 \\
43906 & Karaman-Ayrancı-Akçaşehir & 6116 \\
43937 & Ereğli-Bor & 6021 \\
43967 & Aksaray & 10569 \\
43998 & Altınekin & 1615 \\
44028 & Cihanbeyli-Yeniceoba-Kulu & 4314 \\
44059 & Şereflikoçhisar & 1463 \\
44090 & Misli & 1672 \\
\hline Toplam & & 47816 \\
Tuz Gölü & & 1970 \\
Toplam (Tuz Gölü ve diğer göl yüzey alanları dahil) & 49786 \\
\hline
\end{tabular}

\section{Araştırma Yerinin Iklim Özellikleri}

Orta Toroslar Akdeniz'den gelen yağışların iç̧ Anadolu'ya erişmesini engellediğinden, Toros Dağları'nın Akdeniz'e bakan yamaçları bol yağış alırken, iç kesimlerde yağışlar azalır, yarı kurak veya kurak iklim özellikleri görülür. Havza'nın büyük bir kısmını oluşturan Konya ili geniş bir düz plato üzerine yayılmıştır. Konya Havzası karasal iklime sahiptir. Yazlar sıcak ve kurak olup kışlar soğuk ve az yağışlıdır. Gece-gündüz sıcaklık farkı yaz aylarında $22{ }^{\circ} C^{\prime}$ ye kadar ulaşır. Ocak ayında en düşük ortalama sıcaklık $-0.1{ }^{\circ} \mathrm{C}$ 'dir (Çizelge 2). Ortalama en yüksek sıcaklık Temmuz ayında $23.3{ }^{\circ} \mathrm{C}$ 'dir. Yağış açsından havza, heterojen bir yapı sergileyip 283-766 mm arasında değişim göstermektedir. Havzanın doğusunda $360 \mathrm{~mm}$ düzeyine çıkan ortalama yağış, havzanın orta bölgelerinde özellikle Karapınar çevrelerinde 300 mm'nin de altına inmektedir (Şekil 2). Havzanın batı bölümünde yer alan Seydişehir ve çevresinde 766 mm'ye kadar yükselmektedir.
Havza geneli için ortalama yağış $387 \mathrm{~mm}$ olarak kabul edilmektedir.

\section{Araştırma Yerinin Su Kaynakları}

Konya Havzası'nda yer alan akarsuların çoğu havza içindeki kaynak veya göllerden çıkar. Yağışların düzensizliği ve azlığı sebebiyle akarsuların rejimleri düzensizdir. Kış ve ilkbahar aylarında akışa geçen dereler kurak geçen yaz aylarında kurumakta ya da debileri ciddi ölçüde azalmaktadır. Havza'daki önemli akarsular: Çarşamba Çayı, İvriz Çayı, Deliçay, Melendiz Çayı, Uluırmak ve Peçenek Deresi'dir. Konya Havzası'nın kapalı havza olması sebebiyle akarsular ova tabanlarındaki bataklıklarda kaybolur.

Tuz Gölü, Çavuşçu Gölü, Beyşehir Gölü, Ereğli Ovası'ndaki Akgöl, Hotamış Bataklığı çevresindeki yükseltilerden kaynağını alan dereler kapalı havza şeklindeki bu alanlara akış gösterirler. 
Çizelge 2. Havzaya ait uzun yıllar ortalama sıcaklık, ortalama toplam yağış ve ortalama buharlaşma miktarları (1975-2011)

\begin{tabular}{|c|c|c|c|c|c|c|c|c|c|c|c|c|c|}
\hline \multirow[t]{2}{*}{ İstasyon } & \multicolumn{12}{|c|}{ Aylık Ortalama Sıcaklık $\left({ }^{\circ} \mathrm{C}\right)$} & \multirow{2}{*}{$\begin{array}{c}P \\
(\mathrm{~mm} / \mathrm{yl})\end{array}$} \\
\hline & 1 & 2 & 3 & 4 & 5 & 6 & 7 & 8 & 9 & 10 & 11 & 12 & \\
\hline Aksaray & 0.8 & 1.7 & 6.3 & 12 & 16 & 21 & 24 & 24 & 19 & 13 & 7 & 2.6 & 345 \\
\hline Beyşehir & -0 & 0.6 & 4.8 & 10 & 15 & 19 & 22 & 22 & 18 & 12 & 6 & 1.8 & 489 \\
\hline Cihanbeyli & -0 & 0.7 & 5.2 & 11 & 16 & 20 & 24 & 23 & 18 & 12 & 6 & 1.5 & 321 \\
\hline Ereğli & 0.2 & 1.3 & 6.2 & 12 & 16 & 21 & 24 & 23 & 19 & 13 & 6 & 2 & 306 \\
\hline Karapınar & -0 & 0.5 & 5.1 & 11 & 16 & 20 & 23 & 23 & 18 & 12 & 5 & 1.4 & 284 \\
\hline Konya & 0 & 1 & 5.6 & 11 & 16 & 21 & 24 & 24 & 19 & 13 & 6 & 1.7 & 327 \\
\hline Niğde & -0 & 0.6 & 5.2 & 11 & 15 & 20 & 23 & 23 & 18 & 12 & 6 & 1.7 & 332 \\
\hline Seydişehir & 0.4 & 1.1 & 5.8 & 11 & 16 & 20 & 24 & 24 & 19 & 13 & 7 & 2.3 & 770 \\
\hline Ulukışla & -2 & -1 & 3.5 & 8.9 & 13 & 18 & 22 & 22 & 17 & 11 & 4 & 0.2 & 318 \\
\hline Ortalama & -0.1 & 0.7 & 5.3 & 10.9 & 15.4 & 20.0 & 23.3 & 23.1 & 18.3 & 12.3 & 5.9 & 1.7 & 388 \\
\hline
\end{tabular}

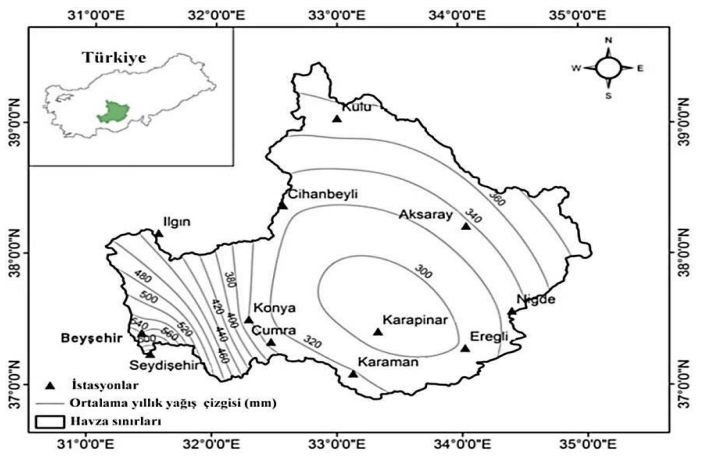

Şekil 2. Konya havzasında yağışın dağılımı

Konya ve Ereğli ovalarının çevresindeki yükseltilerden kaynağını alan dereler ovada kaybolur ve göl oluşturmazlar. Konya Havzası'nın en büyük gölleri Tuz Gölü ve Beyşehir Gölü'dür. Havza içerisindeki düzlüklerde çok sayıda küçük kapasiteli obruk gölleri bulunmaktadır. Havza'nın güneydoğu sınırındaki dağların zirvelere yakın yerlerde ise küçük kapasiteli buzul gölleri mevcuttur.

\section{Küresel Iklim Modeli}

Çalışmada, Meteoroloji Genel

Müdürlüğünün Hadley Merkezi Küresel Çevre Modeli 2 (HadGEM2) kullanarak elde ettiği yağış zaman serileri kullanılmıştır. HadGEM2 küresel iklim modeli, ortak bir fiziksel çerçeve ile farklı karmaşıklık seviyeleri içeren özel model yapılandırmalarının bir dizisini içermektedir (Demircan ve ark., 2017). HadGEM2 ailesi, birleştiğinde atmosfer-okyanus yapılandırması ve/veya dinamik bitki örtüsü, okyanus biyoloji ve atmosferik kimyasıyla Dünya-Sistem yapılandırması ve iyi bir çözümle stratosferin dâhil olduğu atmosferdeki bir dikey uzantısını içerir. Standart atmosferik bileşeni, $1.875^{\circ}$ boylam ve $1.25^{\circ}$ enlem aralığı ile yatay çözünürlüğünden meydana gelen $192 \times 145$ grid hücresinden oluşan küresel bir grid (karelaj) yapısı ve yaklaşık $40 \mathrm{~km}$ yüksekliğe uzanan 38 seviyeye sahiptir (Demircan ve ark., 2017).

\section{Hidrolojik Kuraklığın Belirlenmesi}

Toprak nemi koşulları, nispeten kısa bir zaman diliminde yağış anomalilerine cevap verir. Yeraltı suyu, akarsu ve rezervuar depolama uzun vadeli yağış anomalilerini yansıtır. Bu nedenle, örneğin, meteorolojik kuraklık için 1 veya 6 aylık bir SPI; tarımsal kuraklık için 1 ila 6 aylık bir SPI ve hidrolojik kuraklık için $6-24$ ay (veya daha fazla) SPI analizi iyi sonuçlar verebilir (WMO, 2012). SPI aşağıdaki Eşitlik 1'den yararlanılarak belirlenen zaman dilimi içinde yağışın ortalamadan olan farkının standart sapmaya bölünmesi ile elde edilir (McKee ve ark., 1993).

$$
S P I=\frac{x_{i}-x_{j}}{\sigma}
$$

Eşitlikte; SPI: Standardize Yağış İndisi; Xi: Mevcut Yağış; Xj Ortalama Yağış ve $\sigma$ : standart sapma

SPI analizi kuraklık ve nemlilik sınıflandırmasının sınır değerleri Çizelge 3'de gösterilmiştir. Çalışma kapsamında, kurak dönemler şiddetli kurak ve aşırı kurak sınıflar dikkate alınarak belirlenmiştir. Tatlı ve Türkeş (2011) 12 aylık SPI değerlerinin büyük bir güven düzeyinde PDSI yerine kullanılabileceği belirtilmektedir. Özellikle toprağın su tutma kapasitelerinin bilinmediği elde edilmesinin olanaksız ya da pahalı olduğu durumlarda, 12 aylık SPI indisinin kullanılması önerilmektedir. $\mathrm{Bu}$ bağlamda çalışmada, Standartlaştırılmış Yağış İndisinin (SPI) 12 aylık değerleri dikkate alınarak Konya kapalı havzasının hidrolojik kurak dönemleri tespit edilmiştir. Bilindiği gibi 
SPI meteoroloji, tarımsal ve hidrolojik kuraklıkların belirlenmesinde kullanılan en yaygın yöntemlerden bir tanesidir. SPI basit olmasının yanında son derece de kullanışı bir kuraklık indisidir.

Çizelge 3. SPI Kuraklık/Nemlilik sınıflandırması (McKee ve ark., 1993)

\begin{tabular}{ll}
\hline Standart Yağış & Yağış (Kuraklık/Nemlilik) \\
\hline 2 ve üzeri & Aşırı nemli \\
$1.5-1.99$ & Çok nemli \\
$1-1.49$ & Orta düzeyde nemli \\
$0.5-0.99$ & Normale yakın nemlice \\
$-0.499-0.499$ & Normal \\
$-0.5--0.99$ & Normale yakın kurakça \\
$-1--1.49$ & Orta düzeyde kurak \\
$-1.5--1.99$ & Şiddetli kurak \\
-2 ve altı & Aşırı kurak \\
\hline
\end{tabular}

\section{Jeoistatistiksel Yöntem}

İstatistiğin uygulamalı bir dalı olan jeoistatistik, ilk defa yerbilimlerinde karşılaşılan tahmin problemlerinin çözümüne yönelik olarak kullanılmıştır. Jeoistatistikte ölçüm yapılan notaların konumları ile gözlemler arası korelasyon dikkate alınır. Bu yöntemle yansız ve minimum varyanslı tahminler yapılabilmektedir (Olea, 1977, Başkan, 2004). Ölçülen değerlerden deneysel variogram yapısı belirlenir. Jeoistatistiksel çalışmaların temelini, bu belirlenen variogram yapısına teorik bir modelin uydurulması oluşturmaktadır (Delhomme 1978; Vieira ve ark., 1983; Başkan, 2004). Jeoistatistiksel yöntemler, yönlü verilere uygulandığında oldukça sağlam ve güçlü sonuçlar ortaya koymaktadır.

Haritaların hazırlanmasında Uzaklığın Tersi ile Ağırlıklandırma (Inverse Distance Weighting IDW) enterpolasyon yöntemi kullanılmıştır. IDW, enterpolasyon yöntemi olarak iklim parametrelerinin işlenmesinde kullanılan en yaygın yöntemdir. Yöntemin temeli iki nokta arasındaki ilişkinin ve benzerliğin, aradaki uzaklıkla orantılı olduğu kabulüne dayanır (Aydın ve Çiçek, 2013). Yöntem, araştırılan nokta değerinin yakınındaki bilinen nokta değerlerine daha benzer olacağını kabul etmektedir. Bu varsayımdan yola çıkarak bilinmeyen noktalara yakın olan bilinen noktaların, tahmin edilecek noktanın değeri üzerine daha yüksek etkiye (ağırlığa) sahip olacağı anlaşılmaktadır. IDW yönteminde her örnek noktası, değeri tahmin edilecek noktaya olan uzaklığına ters oranda ağırlık değeri almaktadır (Isaaks ve Srivastava, 1989). Diğer bir ifadeyle bilinmeyen noktanın tahmininde; bilinen noktaların yakın olanlarına daha yüksek oranda ağırlığı olurken uzak olanların ise daha düşük bir ağırlıkta temsili söz konusudur (Franke ve Nielson, 1980; Kale, 2018). Bu nedenle IDW, bilinmeyen mekansal yağış verilerini, bilinmeyen bölgeye bitişik yerlerin bilinen verilerinden tahmin etmek için kullanılabilir (Li ve Heap, 2008; Goovaerts, 2000). IDW formülleri aşağıdaki Eşitlik 2'de verilmiştir. Ayrıca, yöntemde kullanılan ağırlıklandırma Eşitlik 3'de verildiği gibidir.

$\hat{\mathrm{Z}}(\mathrm{X} 0)=\frac{\sum_{i=1}^{N} \mathrm{~W}(\mathrm{Xi}) \mathrm{Z}(\mathrm{Xi})}{\sum_{i=1}^{N} W(\mathrm{Xi})}$
$W(\mathrm{Xi})=\left(\frac{1}{d i}\right)^{P}$

Eşitliklerde; $W(\mathrm{Xi})$ 'inci bilinen konumdaki ağırlı̆̆ı, Z(Xi) 'inci konumdaki bilinen örnek noktası değerini, $\mathrm{N}$ ölçüm noktası sayısını, d örnek noktası ve tahmin noktası arasındaki mesafeyi ve $p$ üstel güç katsayısını ifade etmektedir (Ahrens, 2006).

\section{Bulgular ve Tartışma}

\section{RCP 4.5 iklim Senaryosuna Göre Ortak Kurak Dönemler}

RCP 4.5 İklim senaryosuna göre şiddetli kurak ve aşırı kurak sınıflar dikkate alındığında havzada 6 adet ortak kurak dönem belirlenmiştir. Bunlar sırasıyla 2026 - 2027, 2044 - 2048, 2062 - 2063, 2087 - 2088, 2090 - 2091 ve 2097 - 2098 yıllarını kapsamaktadır. En şiddetli ve uzun olanı da 2044 - 2048 yıllarını kapsayan ortak kurak dönemdir.

\section{6-2027 Hidrolojik Kurak Dönem}

Bu kurak dönem yaklaşık iki yıllık süreyi kapsamaktadır. Her bir istasyon için şiddetli ve aşırı kurak sınıflar dikkate alınarak kuraklık şiddeti hesaplanmıştır. Şekil 3'den de görüleceği gibi, bu hidrolojik orta kurak dönemde havzanın Aksaray, Eskil, Karapınar ve Ayrancı bölümünde, kuraklığın şiddeti daha düşük gerçekleşecektir. Söz konusu bölgede kuraklık şiddet toplamları -5 civarındadır. Havzanın kuzey ve batı bölümlerinde kuraklığın şiddeti dolayısıyla da süresi artmaktadır. Özellikle Kulu'nun doğusundaki Şereflikoçhisar çevresinde, Cihanbeyli'nin kuzeyindeki Turanlar köyünün yanı sıra Hüyük ve Beyşehir çevreleri de bu dönemki kuraklıklardan en fazla 
etkilenecek bölgeler olup kuraklık şiddet toplamları $\quad-20 \quad$ seviyelerine kadar çıkabilmektedir. Havzanın orta bölümlerinde yer alan Cihanbeyli'nin güney kesimleri, Altınekin, Konya ve Çumra bölgeleri, kuzey ve batı bölgelerine göre bir az daha düşük şiddet ve sürede (kuraklık şiddet toplamları -10) kuraklık yaşayacaktır.

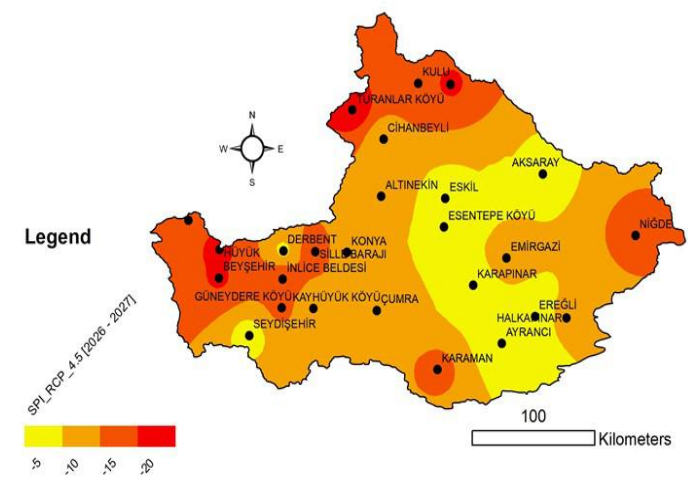

Şekil 3. RCP 4.5 senaryosuna göre 2026-2027 hidrolojik kurak dönemdeki değişim

\section{4-2048 Hidrolojik Kurak Dönem}

$\mathrm{Bu}$ kurak dönem, yaklaşık beş yıllık süreyi kapsamaktadır. Her bir istasyon için şiddetli ve aşırı kurak sınıflar dikkate alınarak kuraklık şiddeti hesaplanmıştır. Şekil 4'den de görüleceği gibi, bu hidrolojik kurak dönemde havzanın özellikle orta bölümünde yer alan, Cihanbeyli, Altınekin, Eskil, Emirgazi, Ereğli, Karapınar ve Ayrancı çevreleri ve de bunların oluşturduğu bölgelerde kuraklığın şiddet toplamları -80'e kadar çıkmaktadır. Söz konusu bölgele havza toplam yüzey alanının yarısını oluşturmaktadır. Bu kurak dönem kuraklık şiddet toplamı -30 civarında olan Çumra çevrelerinde en kısa ve şiddette gerçekleşecektir. Geriye kalan diğer bölgelerde ise kuraklık şiddet toplamları -40 ile -70 arasında değişim sergilemektedirler. Ağırlıklı olarak havzanın batı bölümü ve kısmen de kuzey bölümü, orta bölüme göre daha düşük şiddette kuraklık yaşayacaklardır.

\section{2-2063 Hidrolojik Kurak Dönem}

Bu kurak dönem yaklaşık iki yıllık süreyi kapsamaktadır. Her bir istasyon için şiddetli ve aşırı kurak sınıflar dikkate alınarak kuraklık şiddeti hesaplanmıştır. Şekil 5'den de görüleceği gibi, bu hidrolojik kurak dönemde havzanın kuzey ve kısmen de kuzey batı bölgelerinde kuraklık (kuraklık şiddet toplamı 30), güney ve güney doğu bölgelerine (kuraklık şiddet toplamı -5 ve -10) göre daha ağır yaşanacaktır. Havzanın büyük bölümü kuraklık şiddet toplamı olarak -15 ile -25 arasında değişim sergilemektedir.

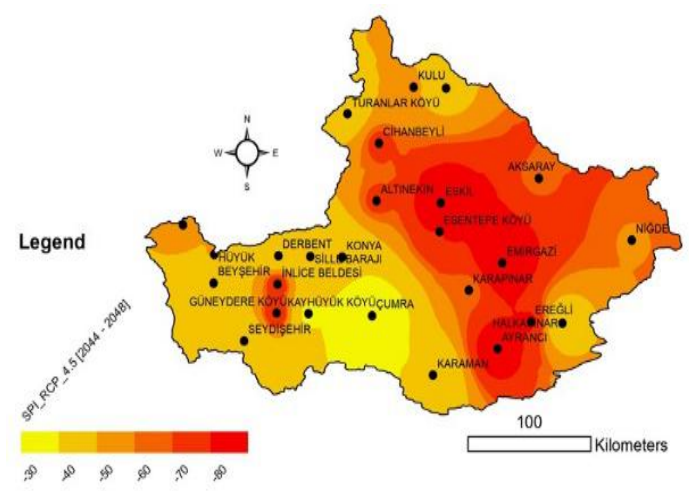

Şekil 4. RCP 4.5 senaryosuna göre 2044-2048 hidrolojik kurak dönemdeki değişim

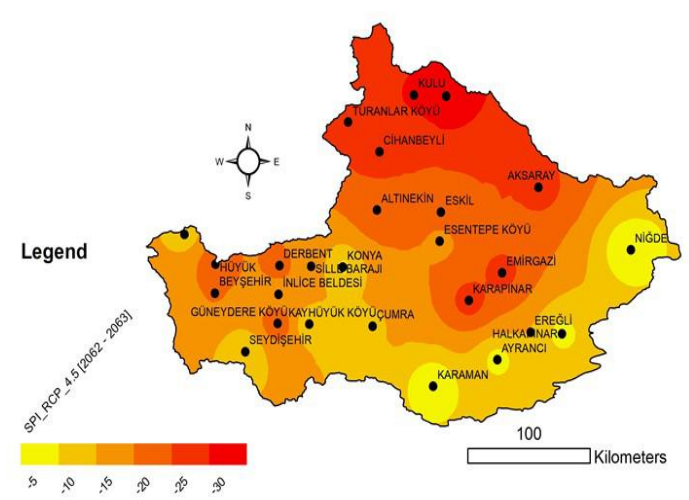

Şekil 5. RCP 4.5 senaryosuna göre 2062-2063 hidrolojik kurak dönemdeki değişim

\section{7-2088 Hidrolojik Kurak Dönem}

Bu kurak dönem yaklaşık iki yıllık süreyi kapsamaktadır. Her bir istasyon için şiddetli ve aşırı kurak sınıflar dikkate alınarak kuraklık şiddeti hesaplanmıştır. Şekil $6^{\prime}$ dan da görüleceği gibi, bu hidrolojik kurak dönemde en az etkilenecek olan bölge Niğde ve Karaman (kuraklık şiddet toplamı -10) çevreleridir. Havzanın kuzeyine ve özelliklede batı bölümünde kalan alanlar hidrolojik kuraklıktan en fazla etkilenecek bölgelerdir. Söz konusu bölgelerde kuraklık şiddet toplamı -50 seviyelerine kadar yükselmektedir. Aksaray, Altınekin, Ereğli ve Çumra çevrelerinin içinde bulunduğu ve havzanın büyük bölümünü kapsayan alanda ise kuraklık şiddet toplamı -20 seviyelerinde olacağı öngörülmektedir.

\section{0-2091 Hidrolojik Kurak Dönem}


Bu kurak dönem yaklaşık iki yıllık süreyi kapsamaktadır.

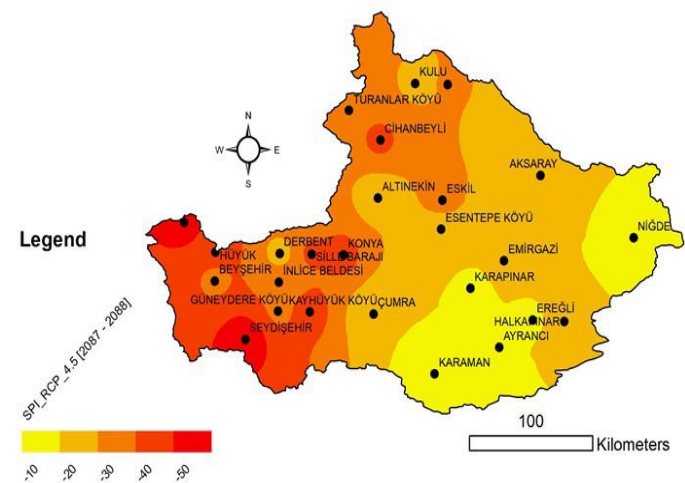

Şekil 6. RCP 4.5 senaryosuna göre 2087-2088 hidrolojik kurak dönemdeki değişim

Her bir istasyon için şiddetli ve aşırı kurak sınıflar dikkate alınarak kuraklık şiddeti hesaplanmıştır. Şekil 7'den de görüleceği gibi, bu hidrolojik kurak dönemde özellikle havzanın Niğde, Ayrancı, Ereğli, Karapınar ve Karaman (kuraklık şiddet toplamı -35) çevreleri en fazla etkilenecektir. Bir önceki hidrolojik kurak dönem olan 2087-2088 hidrolojik kurak dönemi dikkate alındığında tam tersi bir durum söz konusudur. 2090-2091 hidrolojik kurak dönemde Kulu, Cihanbeyli, Konya, Sille Barajı ve Seydişehir çevrelerinde yaşanılacak hidrolojik kuraklık (şiddet toplamı -15), havzanın en az etkilenecek bölgeleri olarak belirlenmiştir. Havzanın büyük bölümü hidrolojik kuraklık açısından şiddet toplamı -25 olacak şekilde söz konusu kuraklığı yaşayacağı öngörülmektedir.

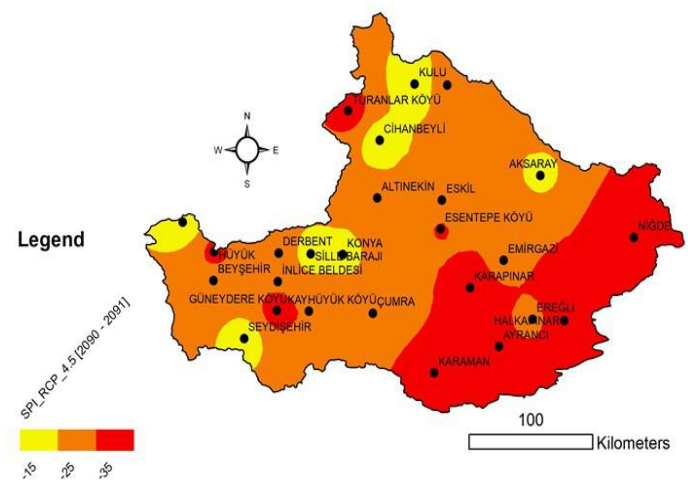

Şekil 7. RCP 4.5 senaryosuna göre 2090-2091 hidrolojik kurak dönemdeki değişim

\section{7-2098 Hidrolojik Kurak Dönem}

Bu kurak dönem yaklaşık iki yıllık süreyi kapsamaktadır. Her bir istasyon için şiddetli ve aşırı kurak sınıflar dikkate alınarak kuraklık şiddeti belirlenmiştir. Şekil 8'den de görüleceği gibi, bu hidrolojik kurak dönemde özellikle havzanın Kulu, Aksaray ve Ayrancı çevreleri (kuraklık şiddet toplamı -5) hidrolojik açıdan en hafif kuraklığı yaşayacaklardır. Genel olarak bakıldığında havzanın batısına doğru kuraklığın şiddet toplamı artmakta ve Karaman, Konya, Sille Barajı, Derbent, Hüyük ve Hüyük'ün kuzey batısında artarak -25'lere kadar yükselmektedir. Söz konusu istasyonlar ve çevreleri kuraklığın en şiddetli olduğu bölgelerdir.

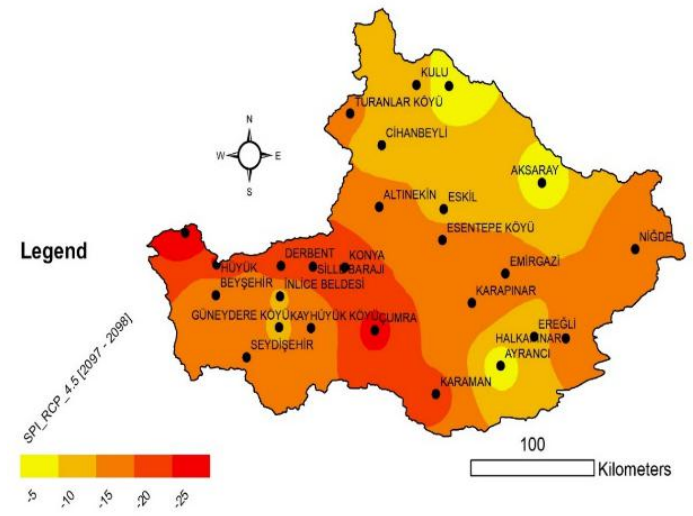

Şekil 8. RCP 4.5 senaryosuna göre 2097-2098 hidrolojik kurak dönemdeki değişim

\section{RCP 8.5 iklim Senaryosuna Göre Ortak Kurak Dönemler}

RCP 8.5 Iklim senaryosuna göre şiddetli kurak ve aşırı kurak sınıflar dikkate alındığında havzada 6 adet ortak kurak dönem belirlenmiştir. Bunlar sırasıyla 2026 - 2027, 2060 - 2063, 2074 - 2075, ve 2092 - 2097 yıllarını kapsamaktadır.

\section{6-2027 Hidrolojik Kurak Dönem}

Bu kurak dönem yaklaşık iki yıllık süreyi kapsamaktadır. Her bir istasyon için şiddetli ve aşırı kurak sınıflar dikkate alınarak kuraklık şiddeti hesaplanmıştır. Şekil 9'dan da görüleceği gibi, bu hidrolojik kurak dönemde özellikle havzanın Kulu ve Şereflikoçhisar çevreleri kuraklığın en fazla etkileyeceği alanlar olup kuraklık şiddet toplamı -40 seviyelerine kadar yükselmektedir. Benzer şekilde Eskil ve Seydişehir ve çevresinde de kuraklık şiddet toplamı -30'a kadar yükselmektedir. Havzanın büyük bölümünde kuraklık şiddet toplamı -20 seviyesindedir. Hidrolojik kuraklık açısında en az etkilenecek bölge Konya, Çumra, Karaman arası bölge ile Niğde ve Karapınar çevresidir. Anılan bölgelerin kuraklık şiddet toplamları -10 seviyesinde olacağı öngörülmektedir. 


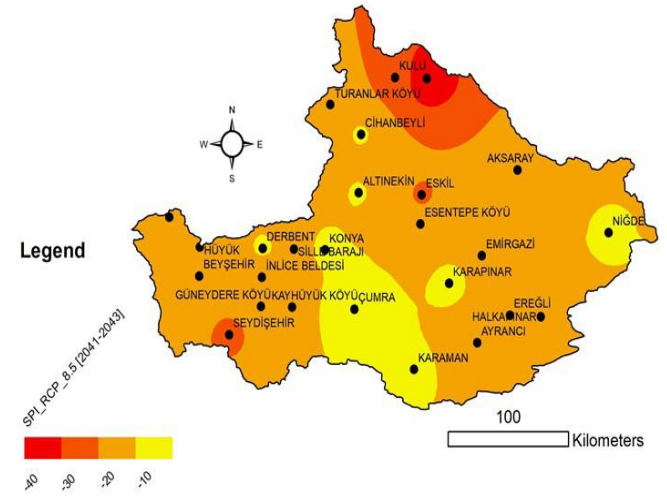

Şekil 9. RCP 8.5 senaryosuna göre 2026-2027 hidrolojik kurak dönemdeki değişim

\section{0-2063 Hidrolojik Kurak Dönem}

Bu kurak dönem yaklaşık iki yıllık süreyi kapsamaktadır. Her bir istasyon için şiddetli ve aşırı kurak sınıflar dikkate alınarak kuraklık şiddeti hesaplanmıştır. Şekil 10'dan da görüleceği gibi, bu hidrolojik kurak dönemde özellikle Kulu, Şereflikoçhisar, Cihanbeyli, Niğde, Ereğli, Karaman, Beyşehir ve Hüyük çevreleri en fazla kuraklığın yaşanacağı bölgeler olup kuraklık şiddet toplamları -50 seviyesine kadar yükselmektedir. Havzanın geneli kuraklık şiddet toplamı olarak ortalama -30 seviyesinde bir şiddette kuraklık yaşayacaktır. Altınekin ve Konya çevresinde küçük bir alanda şiddet toplam -10 seviyesine kadar düşmekte olup en az etkilenecek bölgeler olarak öngörülmektedir.

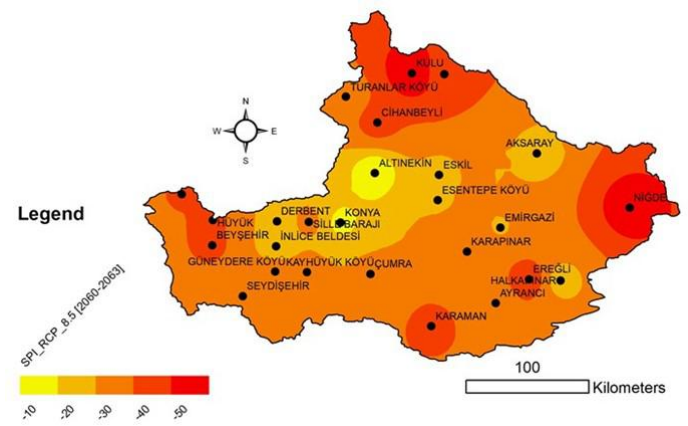

Şekil 10. RCP 8.5 senaryosuna göre 2060-2063 hidrolojik kurak dönemdeki değişim

\section{4-2075 Hidrolojik Kurak Dönem}

Bu kurak dönem yaklaşık iki yıllık süreyi kapsamaktadır. Her bir istasyon için şiddetli ve aşırı kurak sınıflar dikkate alınarak kuraklık şiddeti hesaplanmıştır. Şekil 11'den de görüleceği gibi, bu hidrolojik kurak dönemde özellikle Kulu, Şereflikoçhisar, Cihanbeyli, Karaman, Karapınar, Ayrancı ve Konya çevreleri en fazla kuraklığın yaşanacağı bölgeler olup kuraklık şiddet toplamları -40 seviyesine kadar yükselmektedir. Havzanın batısında yer alana Hüyük, Beyşehir, Güneydere, Derebent istasyonları ile havzanın orta ve doğusunda yer alana Altınekin, Eskil, Esentepe, Emirgazi ve Niğde çevrelerinde kuraklık şiddet toplamları 30 civarında olacak şekilde hidrolojik kuraklık yaşanması olası görünmektedir. Ereğli ve Seydişehir çevrelerinde küçük bir alanın şiddet toplam -10 seviyesine kadar düşmekte olup en az etkilenecek alanlar olarak öngörülmektedir.

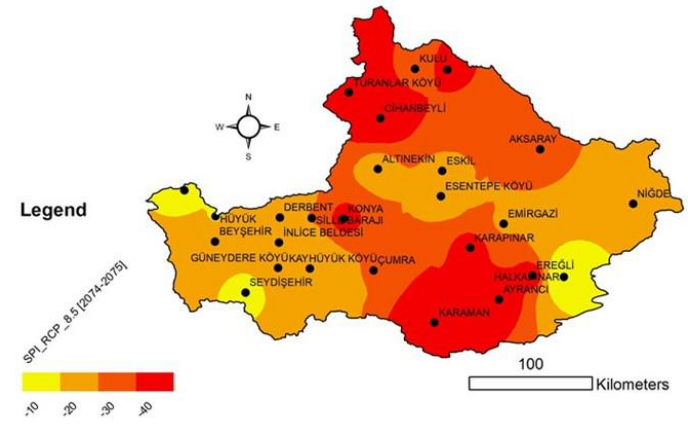

Şekil 11. RCP 8.5 senaryosuna göre 2074-2075 hidrolojik kurak dönemdeki değişim

\section{2-2097 Hidrolojik Kurak Dönem}

Bu kurak dönem yaklaşık Altı yıllık süreyi kapsamaktadır. Her bir istasyon için şiddetli ve aşırı kurak sınıflar dikkate alınarak kuraklık şiddeti hesaplanmıştır. Şekil 12'den de görüleceği gibi, bu hidrolojik kurak dönemde özellikle havzanın Niğde-Ereğli arası, Emirgazi, Karaman, Hüyük Köyü ve Seydişehir çevreleri (kuraklık şiddet toplamı -80 'e kadar yükselmekte) en fazla etkilenecek bölgeler olarak ortaya çıkmaktadır. Havza genelinde dalgalı bir hidrolojik kuraklık söz konusudur. Cihanbeyli ve Kula çevrelerinde kuraklık havzanın diğer bölgelerine göre daha az şiddette ve sürede (şiddet toplamı -30) oluşması beklenmektedir.

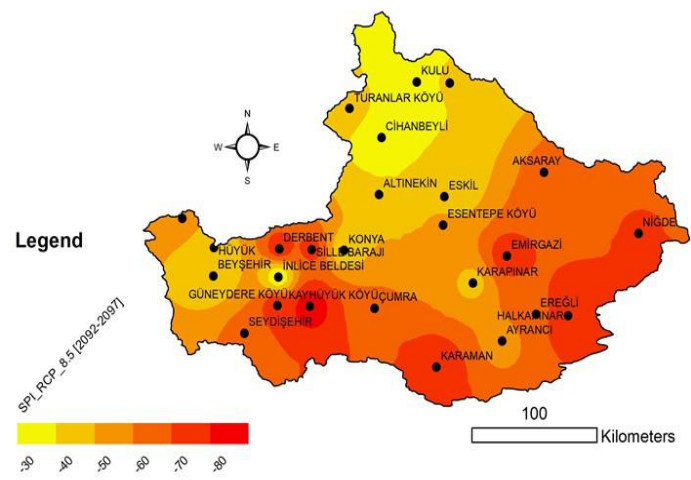


Şekil 12. RCP 8.5 senaryosuna göre 2092-2097 hidrolojik kurak dönemdeki değişim

\section{Sonuçlar}

Meteoroloji Genel Müdürlüğünün HadGEM2 kullanarak elde edilen yağış zaman serileri kullanılarak 2100 yılına kadar Konya Kapalı Havzası için olası ortak hidrolojik kurak dönemler belirlenmiştir. Ortak hidrolojik kurak dönemler belirlenirken iyimser bir senaryo olarak kabul edilen RCP 4.5 senaryosu ve kullanılarak yapılmıştır. Havza içerisinde söz konusu hidrolojik kurak devrelerin şiddetinin nasıl bir dağıldığı gösterdiğinin belirlenmesi ile ağırlıklı olarak hangi bölgelerin ne şiddette etkileneceği saptanmıştır. Bu bilgiler yardımıyla alınacak tedbirlerin düzeyi ve boyutu planlanabilir. Hidrolojik kuraklığın en yaygın etkileri, yağış ve dolayısıyla yüzey akışlarının azalması, toprak neminde görülen açıklar, su depolama yapılarında ve yeraltı suyu seviyelerinde düşüler olarak söylenebilir. Su kalitesi açsından değerlendirildiğinde ise yüksek su sıcaklıklar su kalitesini bozabilmektedir. Ancak, bölgesel olarak daha yoğun akışların etkisi bunu zaman zaman azaltabilir ya da telafi edebilir. Akışın az olduğu durumlarda mutlak suretle su kalitesi bozulmaları artacaktır. Elde edilen sonuçlar, Konya Kapalı Havzasında yaşanması muhtemel olan hidrolojik kurak dönemlerde oluşacak su açığına ve buna bağlı oluşacak krize karşı gerekli önlemelerin alınması ve su yönetimi planlarının hazırlanmasında önemli katkılar sağlayacak niteliklerdedir. Karar vericilerin ve su kullanıcıların, söz konusu yaşanacak kurak dönemlerde kuraklık etkilerini azaltacak önlemler başta olmak üzere, sürdürülebilir canlı yaşamı ve tarımsal üretim için gerekli iş ve işlemleri gerçekleştirmesi çok önemlidir. Doğru planlama ve sorunların çözümüne yönelik önlemler sayesinde hem ülke ekonomisine hem de bölge üreticisine ciddi katkılar sağlanırken aynı zamanda oluşacak zararların azaltılması mümkün kılınabilir. Bu kapsamda Konya Kapalı Havzası'nda bulunan kentsel atık su arıtma tesislerinden deşarj edilen sular sulama suyu kaynağı olarak dikkate alınmalıdır. Havza sınırlarında toplam 8 adet kentsel atık su arıtma tesisi bulunmaktadır. Ancak Aksaray merkez için ise proje aşamasındadır. Hali hazırda havzada Beyşehir $6.66 \mathrm{hm}^{3} / \mathrm{yll}$, Konya Çumra bölgesi $73 \mathrm{hm}^{3} / \mathrm{yll}$, Karaman-Ayrancı bölgesi $8,83 \mathrm{hm}^{3} / \mathrm{yll}$, Ereğli Niğde Bor bölgesi 22,15 $\mathrm{hm}^{3} / \mathrm{yll}$, Cihanbeyli Yeniceoba $\left(5,48 \mathrm{hm}^{3} / \mathrm{yll}\right)$ ve planlama kötümser senaryo olarak ta RCP 8.5 senaryoları dikkate alınmıştır. RCP 4.5 senaryosuna göre Konya Kapalı Havzasında 2100 yılına kadar 2026-2027, 2044-2048, 2062-2063, 2087-2088, 2090-2091 ve 2097-2098 yılları olmak üzere altı hidrolojik kurak dönem belirlenmiştir. RCP 8.5'e göre ise 2026-2027, 2060-2063, 2074-2075 ve 2092- 2097 yılları olmak üzere dört hidrolojik kurak dönem belirlenmiştir. Jeoistatistiksel yöntemle şiddet dağılım haritaları IDW yöntemi

aşamasındaki Aksaray da ise $20,08 \mathrm{hm}^{3} / \mathrm{yıl}$ olmak üzere tüm havzada toplam 136,2 hm3/yıl miktarda atık su üretilmektedir (Anonim, 2019). $\mathrm{Bu}$ nedenle atık suların mutlak bir su kaynağı olarak değerlendirilmesi gerekmektedir. Havzada, bitki kök bölgesi tuzluluğu dikkate alınarak sulama randımanları artırılmalıdır. Öte yandan da su hasadı tekniklerinin havza genelinde benimsetilmesi ve yaygınlaştırılması da büyük öneme haizdir. Sulama suyu gereksinimi daha az olan bitkilerin üretiminin sağlanması ve desteklenmesi gerekmektedir.

\section{Kaynaklar}

Ahrens B., 2006. Distance in spatial interpolation of daily rain gauge data. Hydrology and Earth System Sciences, 10(2), 197- 208.

Anonim, 2012. Faaliyet Raporu 2012. T.C. Orman ve Su İşleri Bakanlığı Devlet Su İşleri Genel Müdürlüğü. Ankara.

Anonim, 2018. Konya Kapalı Havzası Yönetim Planı. Havza Koruma Eylem Planlarının Nehir Havzası Yönetim Planlarına Dönüştürülmesi için Teknik Yardım. TR2011/0327.21-05-01-001

Anonim, 2019. Sektörel Su Tahsisi Eylem Planı ve Genelgesi (2019-2024). Konya Kapalı Havzası Sektörel Su Tahsis Planı Hazırlanması Projesi. T.C. Tarım ve Orman Bakanlığı Su Yönetimi Genel Müdürlüğü. Beştepe Mahallesi, Alparslan Türkeş Cad. No:71, Yenimahalle/Ankara

Aydın, O., ve Çiçek, İ., 2013. Ege bölgesindeki yağışın mekânsal dağılımı. Coğrafi Bilimler Dergisi, 11 (2), 101-120.

Başkan, O. 2004. Gölbası yöresi topraklarının mühendislik, fiziksel özellik ilişkilerinde jeoistatistik uygulaması, Doktora Tezi, AÜ, Fen Bilimleri Enstitüsü, (Basılmamış) Ankara. 
Delhomme, JP 1978. Kriging in the Hydrosciences. Advances in Water Resources,1(5): 251-266.

Demircan M., Arabacı H., Gürkan H., Eskioğlu O., Coşkun M., 2017. Climate Change Projections for Turkey: Three Models and Two Scenarios, Türkiye Su Bilimi ve Yönetimi Dergisi (Turkish Journal Of Water Science \& Management), ISSN:2536 474X Publication number:6777, Volume: 1 Issue: 1, January 2017, Ankara

Franke, R., Nielson, G., $1980 . \quad$ Smooth interpolation of large sets of scattered data. International Journal for Numerical Methods in Engineering, 15, 1691-1704.

Goovaerts P., 2000. Geostatistical Approaches for Incorporating Elevation into the Spatial Interpolation of Rainfall. Journal of Hydrology, Vol. 228, No. 1-2, 2000, pp. 113129. http://dx.doi.org/10.1016/S00221694(00)00144-X

Gürler Ç., 2017. Beyşehir ve Konya-ÇumraKarapınar Alt Havzalarında Standartlaştırılmış İndis Yaklaşımı İle Hidrolojik Kuraklık Değerlendirmesi. Uzmanlık Tezi. T.C. Orman ve Su Iş̧leri Bakanlığı, Su Yönetimi Genel Müdürlüğü. Ankara

Isaaks, E., and Srivastava, R., 1989. An Introduction to Applied Geostatistics. Oxford University Press, New York.

Kale M.M., 2018. Yeşilırmak Havzası Mekânsal Yağış Dağılımına ait Değişiminin Deterministik ve Stokastik Yöntemlerle Belirlenmesi. Yerbilimleri, 2018, 39 (3), 263-276

Li J., Heap A. D., 2008. A Review of Spatial Interpolation Methods for Environmental Scientists. Geoscience Australia, Canberra, 2008.

McKee T., Doesken N., Kleist J., 1993. The relationship of drought frequency and duration to time scale. Proceedings of the Eighth Conference on Applied Climatology (s. 179-184). Anaheim, California: American Meteorological Society.

Olea R.A., 1977. Measuring spatial dependence with semivariograms. kansas geological survey, series on spatial analysis, No. 3, Lawrance, Kansas. p. 122

Şen Z., 2005. İklim Değişikliği ve Su Kaynaklarına Etkisi. 22 Mart Dünya Su Günü, "Iiklim
Değişikliğinin Su ve Enerji Kaynaklarımıza Etkisi"Paneli (2005). Lütfi Kırdar Kongre ve Sergi Sarayı - Marmara Salonu, İstanbul.

Tatli H., Türkeş M., 2011. Comparison of The Palmer Drought Severity Index With The Standardized Precipitation Index Over Turkey. 5th Atmospheric Science Symposium, İstanbul, Türkiye, 27-29 Nisan 2011, pp.231-239

Vieira SR, Hatfield JL, Nielsen DR, Biggar JW 1983. Geostatistical theory and application to variability of some agronomical properties. Hilgardia, 51 (3): 1-75, Davis- California

WMO, 2012. Standardized Precipitation Index User Guide. World Meteorological Organization. 